\title{
Pigmented plaque on the thigh: Atypical location of a basal cell carcinoma
}

\section{Samia Mrabat, Zakia Douhi, Sara Elloudi, Hanane Baybay, Fatima Zahra Mernissi}

\author{
Department of Dermatology, University Hospital Hassan II, Fes, Morocco
}

Corresponding author: Samia Mrabat, MD, E-mail: samiamrabat91@gmail.com

Basal cell carcinoma (BCC) is the most common type of skin cancer, usually occurring on sun-exposed areas, such as the head and neck [1]. Chronic sun exposure is the cause of most of its cases but it may also develop on unexposed areas. BCC on extrafacial sites accounts for $17 \%$ of all basal cell carcinomas [2] . In these cases, dermoscopy can be especially helpful in diagnosis.

A 43-year-old female presented herself with a slowly growing, slightly itchy pigmented lesion on the right thigh persistent for the past two years. A clinical examination revealed a $2-\mathrm{cm}$ well-limited pigmented plaque with excoriations on the periphery (Fig. 1). Dermoscopy showed multiple maple-leaf-like areas, digitiform structures

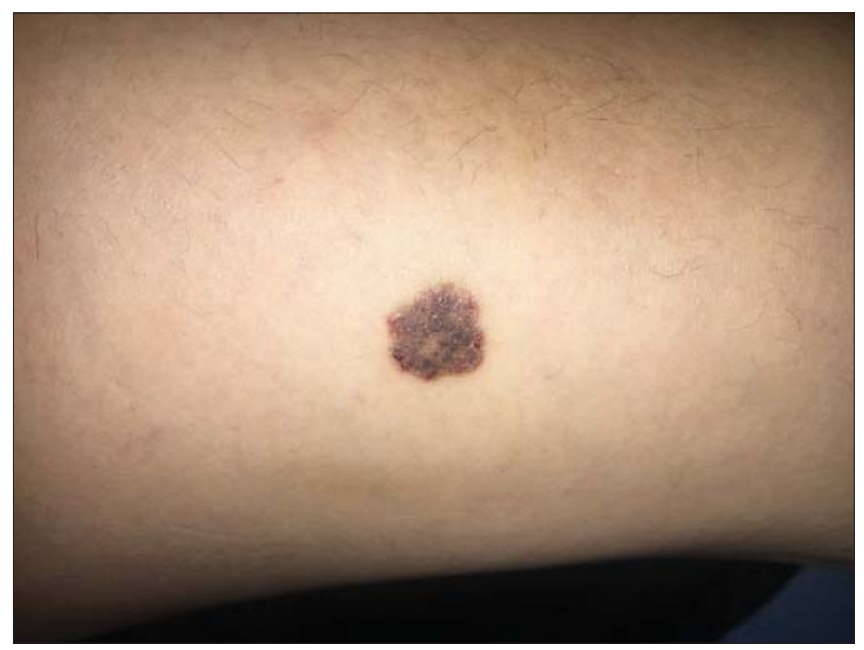

Figure 1: Clinical image showing a 2-cm well-limited pigmented plaque with excoriations on the periphery. with rosettes (Fig. 2). The lesion was subsequently excised with 6-mm margins. A histopathological report confirmed the diagnosis of superficial basal cell carcinoma with clear margins.

\section{Consent}

The examination of the patient was conducted according to the principles of the Declaration of Helsinki.

The authors certify that they have obtained all appropriate patient consent forms, in which the patients gave their consent for images and other clinical information to be included in the journal. The patients understand that their names and initials will not be published and due effort will be made to conceal their identity, but that anonymity cannot be guaranteed.

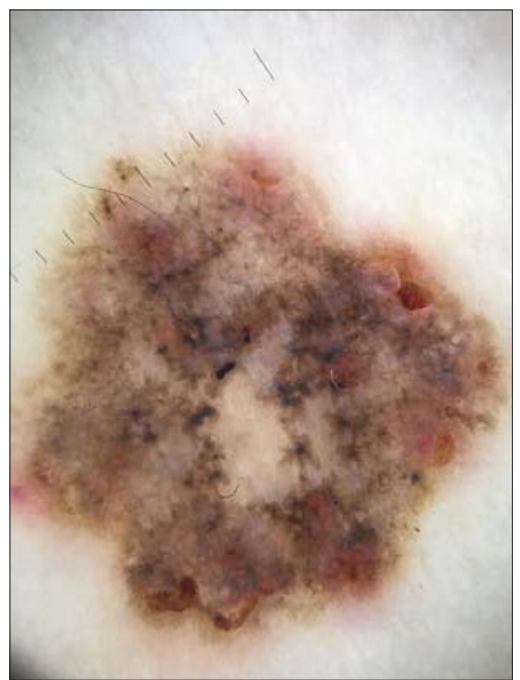

Figure 2: Dermoscopic image showing multiple maple-leaf-like areas digitiform structures with rosettes.

How to cite this article: Mrabat S, Douhi Z, Elloudi S, Baybay H, Mernissi FZ. Pigmented plaque on the thigh: Atypical location of a basal cell carcinoma. Our Dermatol Online. 2021;12(2):195-196.

Submission: 28.08.2020; Acceptance: 31.10 .2020

DOI: $10.7241 /$ ourd.20212.24 
www.odermatol.com

\section{REFERENCES}

1. Roh SG, Park J, Song KH, Nam KH, Yun SK, Kim HU. Clinical and histopathological characteristics of extra-facial basal cell carcinoma: Analysis of 35 patients at the Chonbuk National University Hospital in Korea. Australas J Dermatol. 2014;55:e65-8.

2. Scrivener Y, Grosshans E, Cribier B. Variations of basal cell carcinomas according to gender, age, location and histopathological subtype. Br J Dermatol. 2002;147:41-7.

Copyright by Samia Mrabat, et al. This is an open-access article distributed under the terms of the Creative Commons Attribution License, which permits unrestricted use, distribution, and reproduction in any medium, provided the original author and source are credited.

Source of Support: Nil, Conflict of Interest: None declared. 